\title{
IMPLEMENTASI PENYELESAIAN SENGKETA WARISAN DI LUAR PENGADILAN
}

\author{
Sri Khayati \\ Universitas Sulawesi Tenggara
}

\begin{abstract}
ABSTRAK
Penelitian ini bertujuan untuk mengetahui impelementasi penyelesaian perkara warisan yang terjadi pada umumnya di masyarakat desa Moolo Kecamatan Batukara Kabupaten Muna dan untuk mengetahui alasan-alasan masyarakat desa Moolo kecamatan Batukara kabupaten Muna menggunakan penyelesaian perkara warisan di luar pengadilan. Penelitian dilakukan di desa Moolo Kecamatan Barukara maka metode pendekatan yang dipakai adalah yuridis sosiologis yang dilakukan berdasar penelitian yang disusun secara sistematis dan terkontrol atas dasar empiris yang diperoleh dari masyarakat. Kemudian seluruh data yang ada dianalisa secara deskriptif analitis. Hasil penelitian menunjukan bahwa sistem Berdasar hasil penelitian, penulis memperoleh jawaban atas permasalahan yang ada yaitu implementasi penyelesaian perkara warisan yang terjadi pada umumnya di desa Moolo Kecamatan Batukara kabupaten Muna adalah selalu menggunakan musyawarah mufakat untuk menyelesaikannya. Hal ini menunjukan bahwa hukum waris adat masih sangat kuat ada pada masyarakat desa Moolo Kecamatan Batukara Kabupaten Muna, mengalahkan hukum waris islam dan lebih-lebih hukum waris barat (BW). Sedangkan, alasan-alasan masyarakat desa Moolo Kecamatan Batukara Kabupaten Muna menggunakan penyelesaian perkara warisan di luar pengadilan adalah, karena membagi dengan cara seperti ini mengikuti jejakjejak orang tuanya lebih dahulu atau nenek moyang atau leluhur yang telah mengajarkan kepada mereka. Selain itu, mereka juga berpedoman bahwa harta peninggalan orang tua itu tabu untuk diperebutkan. Selain kedua alasan itu, ada alasan yang sangat fundamental bagi mereka yaitu mereka berpedoman Tuhan maha kaya. Selain itu masih ada alasan lain, yaitu harta peninggalan orang tua harus dilestarikan sebaik-baiknya dalam artian bahwa harta peninggalan dari si pewaris itu harus dijaga sebaik-baiknya, tidak boleh dipergunakan atau bahkan dijual dengan hasilnya dipergunakan untuk keperluan yang tidak penting.
\end{abstract}

Kata kunci: penyelesaian sengketa warisan

\section{PENDAHULUAN}

Kehidupan manusia dibutuhkan kecukupan papan, sandang dan pangan sekaligus merupakan kebutuhan primer, hal tersebut tidak mungkin bisa dipisahkan. Begitu juga hubungan antara manusia, manusia tidak mampu berdiri sendiri,tanpa manusia lain,karena antara manusia saling "tak and give atau memberi dan menerima yang selalu saling membutuhkan.

Dari gambaran diatas hubungan antara manusia tidak bisa selamanya baik, masalah demi masalah akan selalu ada dan timbul menyertai perjalanan hidup manusia, sehingga untuk menyelesaikan masalah-masalah tersebut perlu adanya suatu kesatuan pendapat, tanpa dilandasi emosi dan 
paksaan yang nantinya timbul hubungan yang harmonis dan kerukunan antara umat manusia.

Perkembangan masyarakat yang begitu pesat, baik dari segi jumlah maupun segi perhubungan hukum antara anggota masyarakat yang satu dengan anggota yang lain, maka kemungkinan terjadinya bentrokan kepentingan diantara mereka semakin besar, padahal semua warga masyarakat menginginkan keadilan dan kepastian hukum sebagai jaminan atas haknya.

Mengingat perkembangan yang demikian, jumlah sengketa yang masuk ke Pengadilan menjadi semakin bertumpuk dan semuanya membutuhkan penyelesaian. Akan tetapi mengingat jumlah Hakim yang terbatas ditambah lagi dengan prosedur pemeriksaan perkara yang di tuntut ketelitian, mana diharapkan menghasilkan putusan yang adil dan bermanfaat, maka banyak sengketasengketa yang penyelesaiannya sampai berbulan-bulan, atau bahkan sampai bertahun-tahun. Belum lagi jika ada pihak-pihak yang tidak puas dengan apa yang diputuskan oleh Hakim dan mengajukan Banding atau Kasasi, maka sengketa akan terkatung-katung lebih lama lagi.

Dari sitidapat dilihat sebagai misal, bahwa akibat dari lamanya proses pemeriksaan sengketa di pengadilan dalam sengketa mengenai Pembagian Harta Warisan, maka status harta warisan itu menjadi terkandas atau terkatung-katung dan tidak mempunyai kepastian hukum yang tetap, padahal kemungkinan juga para ahli warisnya sangat membutuhkan harta warisan tersebut untuk keperluan hidupnya Akibat seperti tersebut di atas mestinya dapat dihindari andaikata mereka/para pihak mau melakukan penyelesaian perkara warisan tersebut di luar pengadilan, atau dengan kata lain mau melakukan perdamaian dalam menyelesaikan sengketa warisan tersebut. Penyelesaian sengketa warisan diluar pengadilan/dengan kata lain dengan perdamaian, yaitu dengan mengorbankan barang sedikit haknya yang dituntut semula, atau melakukan sesuatu yang mana akhirnya dapat dicapai suatu perdamaian diantara mereka sehingga perkara tidak sampai masuk pengadilan.

Di desa Moolo Kecamatan Batukara Kabupaten Muna, masyarakatnya sebagian besar bersifat homogen. Hal ini dapat dilihat dari aktifitas masyarakatnya yang cenderung sama dalam keseharihariannya. Mulai dari kesamaan pekerjaan sampai dalam menganut kepercayaan (agama).

Mereka bekerja sebagian besar sebagai petani, nelayan. Mereka berangkat secara bersama-sama, dengan berkumpul pada satu tempat tertentu (warung kopi) sebelum pergi ke ladang. Dalam agama, sebagian besar mereka beragama islam. Hal ini dapatdilihat dari KTP (Kartu Tanda Penduduk) mereka yang menyatakan bahwa mereka menganut agama islam. Di samping itu, kegiatan-kegiatan seperti pengajian sering diadakan di musholamushola/Masjid.

Sehingga apabila ada masalahmasalah dalam keluarga ataupun masyarakat, mereka cenderung melakukannya secara musyawarah atau meminta pendapat yang lebih tua untuk menyelesaikannya. Dengan didasarkan pada ajaran islam sebagai landasannya. 
Masalah-masalah yang timbul dimasyarakat, umumnya adalah masalah mengenai pembagian warisan. Karena pembagian warisan merupakan hal yang mau tidak mau, pasti dialami oleh setiap orang yang mempunyai warisan. Apalagi pada masyarakat pedesaan, yang pada umumnya mempunyai warisan berupa tanah yang tidak sedikit jumlahnya. Mengenai pembagian warisan tersebut, mayarakat di desa Moolo Kecamatan Batukara Kabupaten Muna, pada umumnya melakukan pembagian warisan secara kekeluargaan/secara waris adat. Tetapi tidak sedikit pula yang membagi warisan dengan menggunakan sistem hukum waris islam, tetapi cara pelaksanaanya pembagian warisannya secara musyawarah. Untuk pembagian warisan secara Hukum Waris Barat (BW), jarang ditemukan di dalam masyarakat.

Berangkat dari permasalahan diatas,maka dalam penelitian ini penulis mengambil Judul "Implementasi Penyelesaian Sengketa Warisan diluar Pengadilan" Studi di Desa Moolo Kecamatan Batukara Kabupaten Muna.

\section{Rumusan Masalah}

1. Faktor-faktor Apakah yang menyebabkan masyarakat Desa Moolo kecamatan Batukara KabupatenMuna menggunakan penyelesaian sengketa warisan diluar pengadilan?

2. Bagaimana implementasi penyelesaian sengketa warisan yang terjadi pada umumnya di masyarakat Desa Moolo Kecamatan Batukara Kabupaten Muna?

\section{Tujuan Penelitian}

Tujuan penelitian ini dilakukan adalah sebagai berikut :

1. Untuk mengetahui dan memahami Faktor-faktor yang menyebabkan masyarakat Desa Moolo Kecamatan Batukara Kabupaten Muna menggunakan penyelesaian sengketa warisan diluar pengadilan.

2. Untuk mengetahui dan memahami Implementasi penyelesaian perkara warisan yang terjadi pada umumnya di masyarakat Desa Moolo Kecamatan Batukara Kabupaten Muna.

\section{Kegunaan Penelitian}

Apapun kegunaan penelitian ini adalah sebagai berikut yaitu :

1. Secara teoritis sebagai sumbangan pemikiran dalam upaya mengembangkan ilmu pengetahuan hukum perdata yang berhubungan dengan penyelesaian sengketa warisan diluar pengadilan sehingga dapat menambah wawasan pengetahuan, konsep metode, maupun pengembangan teori dibidang hokum perdata khususnya dibidang penyelesaian sengketa warisan diluar pengadilan.

2. Sebagai masukan kepada masyarakat yang berperkara warisan, agar mengutamakan penyelesaan sengketa warisan diluar pengadilan.

\section{METODE PENELITIAN}

\section{A. Lokasi Penelitian}

Penelitian ini dilakukan di

Desa Moolo Kecamatan Batukara Kabupaten Mauna. Pemilihan 
lokasi ini didasarkan pada pertimbangan bahwa masalah implementasi penyelesaian sengketa warisan diluar pengadilan, di Desa Moolo Kecamatan Batukara Kabupaten Muna hampir dipergunakan di setiap keluarga.

\section{B. Teknik Pengumpulan Data}

Teknik pengumpulan data penelitian dilakukan melalui:

1. Studi Lapangan

a. Observasi

Teknik

observasi

dilakukan untuk mengumpulkan data dengan menggunakan pengamatan langsung terhadap implementasi penyelesaian perkara warisan diluar pengadilan.

b. Wawancara atau komunikasi

Wawancara atau Komunikasi yaitu teknik pengumpulan data dengan cara tanya jawab secara sistematis dengan tatap muka, hal ini untuk mengetahui apa yang terkandung dalam pikiran dan hati orang yang melakukan penyelesaian sengketa warisan. Dalam penelitian ini menggunakan wawancara terstruktu yaitu wawancara yang pewawancaranya

menetapkan sendiri masalah dan pertanyaan yang akan diajukan.

2. Studi kepustakaan dan dokumentasi:

Dengan cara membaca, menyalin dan mengcopy buku literatur, artikel, jurnal ilmiah yang berkaitan dengan penelitian ini. Studi kepustakaan dan dokumentasi merupakan salah satu bentuk metode dimana penelitian menggunakan buku literatur, artikel, jurnal ilmiah, pendapat para ahli serta dokumen lain yang relevan dengan penelitian ini sehingga dapat digunakan sebagai pedoman penulisan penelitian ini.

\section{Jenis dan Sumber Data}

Jenis Data

Dalam data primer ini mengandung data aktual yang didapat dari penelitian lapangan. Data primer dalam penelitian ini adalah berupa penyelesaian sengketa waris yang pernah dilakukan masyarakat di desa Moolo kecamatan Batukara Kabupaten Muna, alasan-alasan masyarakat desa Moolo Kecamatan Batu Kara kabupaten Muna menggunakan penyelesaian sengketan warisan diluar pengadilan.

Sumber Data

Data yang didapatkan melalui studi kepustakaan, hasil penelitian yang telah dilakukan, dan dokumen yang berkaitan dengan pelaksanaan pembagian warisan, khususnya diluar pengadilan. Data sekunder diperoleh dari perpustakaan universitas, pusat dokumentasi dan informasi hukum.

\section{Analisis Data}

Teknik analisis data yang dipakai adalah teknik deskriptif kualitatif yaitu berusaha menganalisa data dengan menguraikan dan memaparkan 
secara jelas dan apa adanya mengenai obyek yang diteliti, datadata dan informasi yang diperoleh dari obyek penelitian, dikaji dan dianalisa dikaitkan dengan teori dan peraturan yang berlaku bertujuan untuk memecahkan permasalahan yang diangkat .Dari hal tersebut kemudian ditarik suatu kesimpulan.

\section{HASIL DAN PEMBAHASAN}

\section{A. Faktor-faktor Masyarakat desa Moolo Kecamatan Batukara Kabupaten Muna Menggunakan Penyelesaian Sengketa Warisan diluar pengadilan.}

Masyarakat Desa Moolo Kecamatan melakukan pembagian warisan, dari data 10 responden yang ada menyatakan bahwa mereka melakukan pembagian warisan secara Hukum Waris Adat. Dalam melaksanakan atau membagi warisan, mereka menggunakan cara musyawarah mufakat, para ahli waris berkumpul untuk membicarakan harta warisan dari si pewaris untuk segera membagi kepada mereka (ahli waris).

Di dalam musyawarah, para ahli waris menunjuk anak laki-laki tertua atau kalau yang tertua perempuan, maka tetap anak lakilaki dari saudara-saudaranya yang perempuan sebagai juru bagi. Anak laki-laki tertua atau anak laki-laki dari saudara-saudranya yang perempuan ini, yang memutuskan mengenai bagianbagian warisan dari masing-masing saudaranya. Juru bagi membagi warisan dari harta warisan si pewaris berdasarkan musyawarah mufakat para ahli waris, tidak atas kehendaknya sendiri.

Di dalam musyawarah, para ahli waris tidak ada satupun yang memprotes keputusan yang telah diputuskan oleh juru bagi yang ditunjuk oleh para ahli waris itu sendiri. Karena selain membagi dengan cara seperti ini mengikuti jejak-jejak orang tuanya lebih dahulu atau nenek moyang atau leluhur yang telah mengajarkan kepada mereka. Mereka juga berpedoman bahwa harta peninggalan orang tua itu tabu untuk diperebutkan. Kalau sudah dinyatakan tabu, maka tidak akan pernah persoalan tersebut dipersoalkan Diperbincangkan saja antar para ahli waris tidak pernah terdengar. Jadi para ahli waris telah menyadari bahwa apa yang telah diajarkan orang tuanya lebih dahulu atau leluhur atau nenek moyang harus diikuti, tanpa mencari-cari sebabnya. Karena kalau melanggar apa yang telah deperintahkan oleh orang tuanya terlebih dahulu atau leluhur atau nenek moyang, dalam keyakinan mereka adalah berdosa.

Selain kedua alasan itu, ada alasan yang sangat fundamental bagi mereka yaitu mereka berpedoman Tuhan maha kaya. Alasan inilah yang menjadi keyakinan bahwa berapapun jumlah bagian warisan yang diterimanya adalah sedikit dibandingkan dengan kekayaan tuhan yang tidak ada batasnya. Alasan yang seperti ini menandakan bahwa keimanan dan ketakwaan masyarakat Desa Moolo Kecamatan Batukara Kabupaten Muna kepada Tuhan sangatlah kuat. Kalau udah menyangkut keyakinan 
kepada Tuhan maka sangatlah sulit untuk dirubah keyakinan tersebut. Dan hal ini berkaitan dengan pelaksanaan pembagian warisan pada masyarakat Desa Moolo Kecamatan Batukara Kabupaten Muna.

Selain itu masih ada alas an lain mengapa masyarakat Desa Mool Kecamatan Batukara Kabupaten Muna membagi harta peninggalan si pewaris secara Hukum Waris Adat, yaitu harta peninggalan orang tua harus dilestarikan sebaik-baiknya dalam artian bahwa harta peninggalan dari si pewaris itu harus dijaga sebaik-baiknya, tidak boleh dipergunakan atau bahkan dijual dengan hasilnya dipergunakan untuk keperluan yang tidak penting. Harta peninggalan sipewaris boleh digunakan asalka untuk keperluankeperluan yang mendesak bagi keperluan ahli waris. Penggunaan harta peninggalan si pewaris untuk keperluan para ahli waris, ini diputuskan melalui musyawarah mufakat.

Maka berdasarkan alasanalasan tersebut, masyarakat Desa Moolo Kecamatan Batukara Kabupaten Muna dalam melaksana kan pembagian warisan dari si pewaris, adalah dengan menggunakan cara musyawarah mufakat dari para ahli waris. Selama melakukan musyawarah mufakat tidak pernah ada hambatan. Semua berjalan lancar selama musyawarah, karena musyawarah dilakukan untuk mencapai kata sepakat dengan menampung semua pendapat atau usulan, menyalurkan dan menyimpulkan usul pedapat dari para ahli waris tentang bagaimana sebaiknya harta warisan itu dibagibagi.

\section{B. Implementasi Penyelesaian} Sengketa Warisan yang Terjadi pada Umumnya di Masyarakat Moolo Kecamatan Batukara Kabupaten Muna.

Warisan adalah harta kekayaan dari pewaris yang telah wafat, baik harta itu telah dibagi atau masih dalam keadaan tidak terbagi-bagi. Istilah ini dipakai untuk membedakan dengan harta yang didapat seseorang bukan dari peninggalan pewaris tetapi didapat sebagai hasil usaha pencaharian sendiri didalam ikatan atau diluar ikatan perkawinan.

Warisan tersebut diberikan kepada para waris. Para waris adalah semua orang yang (akan) menerima penerusan / pembagian warisan baik ia sebagai ahli waris yaitu orang yang berhak mewarisi maupun yang bukan ahli waris tetapi mendapat warisan.Pada umumnya para waris ialah anak termasuk anak dalam kandungan ibunya jika lahir hidup, tetapi tidak semua anak adalah ahli waris, kemungkinan para waris lainnya seperti anak tiri, anak angkat, anak piara, waris balu, waris kemenakan, dan para waris pengganti seperti cucu,ayah-ibu, kakek-kakek,waris anggota kerabat dan waris lainnya. Kemudian berhak tidaknya para waris tersebut dipengaruhi oleh sistem kekerabatan bersangkutan dan mungkin juga karena pengaruh agama, sehingga antara daerah yang satu dan yang lain terdapat perbedaan. 
Adapun cara pembagiannya adalah berbeda-beda, sesuai dengan hukum waris mana yang dipilih oleh para ahli waris untuk membagi warisan tersebut. Dinegara indonesia, dikenal ada tiga pilihan hukum waris yang dipakai yaitu Hukum Waris Adat, hukum waris islam, Hukum Waris Barat (BW).

Masyarakat di daerah satu dengan daerah lainnya adalah berbeda-beda. Asas kesamaan hak sesuai dengan perkembangan masyarakat yang modern, terutama bagi keluarga-keluarga yang telah maju dan bertempat tinggal di kota-kota dimana alam fikiran yang cenderung kepada sifat-sifat yang individualistis telah mempengaruhi dan ikatan kekerabatan mulai merenggang.

Sedangkan asas kerukunan asas saling mengerti dan memahami kepentingan yang satu dan yang lain, dimana hidup saling menunjang di utamakan, terlihat masih berpengaruh dilingkungan masyarakat desa dimana hubungan kekerabatan dan sifat-sifat komunal masih kuat. Keadaan masyarakat seperti inilah yang menjadi dasar ahli waris menentukan hukum waris yang akan dipakai untuk menyelesaiakan peminpin.Di daerah pedesaan, masyarakat umumnya memilih membagiwarisan secara HukumWaris Adat (musyawarah/kekeluargaan).

Sedangkan kalau di daerah perkotaan, mayarakat umumnya memilih membagi warisan secara Hukum Waris Barat (BW).

Desa Moolo kecamatan Batukara Kabupaten Muna mempunyai luas wilayah lebih kurang 3000 x 3000 meter persegi. Dimana sebelah utara berbatasan dengan desa Lanobake sebelah timur berbatasan dengan Hutan Lindung, sebelah selatan berbatasan dengan desa Baluara dan sebelah barat berbatasan dengan Hutan Bakau. Dengan jumlah penduduk desa Moolo Kecamatan Batukara Kabupaten Muna adalah sebanyak 273 kepala keluarga.

Dari 273 kepala keluarga ini ada yang sudah melakukan warismewaris, tapi ada juga yang belum.Dari 273 kepala keluarga diambil responden sebanyak 10 kepala keluarga untuk mewakili jumlah masyarakat desa Moolo Kecamatan Batukara Kabupaten Muna yang pernah melakukan waris-mewaris.

Semua responden beragama islam dan pernah melakukan waris- mewaris, baik sebagai ahli waris maupun sebagai pewaris.Walaupun mereka beragama islam dan menjalankan ajaran agama islam dengan sungguh-sungguh, tapi kalau urusan waris-mewaris mereka menyelesaikannya tetap menggunakan Hukum Waris Adat. Hal ini menunjukan bahwa Hukum Waris Adat masih sangat kuat ada pada masyarakat desa Moolo Kecamatan Batukara Kabupaten Muna, mengalahkan hukum waris islam dan lebih-lebih Hukum Waris Barat (BW).

Kuatnya penggunaan Hukum Waris Adat dalam hal warismewaris, mengalahkan hukum waris islam dan Hukum Waris Barat (BW) adalah karena dalam 
pikiran masyarakat desa Moolo Kecamatan Batukara Kabupaten Muna menyelesaikan warismewaris dengan bagaimana baiknya lebih bagus dibandingkan dengan menyelesaikan waris-mewaris yang diatur oleh adanya suatu ketentuan. Pembagian warisan yang diatur oleh suatu ketentuan hanya akan menimbulkan rasa ketidak ikhlasan di hati mereka (ahli waris). Masyarakat Desa Mool Kecamatan Batukara Kabupaten Muna mempunyai prinsip bahwa segala sesuatu itu harus dilandasi dengan rasa ikhlas. Mengenai cara pembagian waris masyarakat Desa Moolo Kecamatan Batukara Kabupaten Muna selalu menggunakan musyawarah mufakat untuk menyelesaikan pembagian warisan.Para ahli waris berkumpul untuk melakukan musyawarah setelah menerima warisan dari Pewaris. Dalam musyawarah saudara yang tertua laki-laki atau kalau yang tertua perempuan, maka tetap anak laki-laki dari saudarasaudara perempuannya yang memimpin jalannya musyawarah dan yang memutuskan bagian masing-masing ahli waris. Anak laki-laki tertua atau anak laki-laki dari saudara-saudaranya yang perempuan disebut sebagai juru bagi. Mereka yang menjadi juru bagi sesungguhnya bukan juru bagi yang mutlak haru diturut ketetapan pembagiannya, tetapi mereka itu hanya sebagai juru damai, sebagai pembawa acara yang memimpin pertemuan untuk mencapai kata sepakat, mereka bertugas menampung, menyalurkan dan menyimpulkan usul pendapat dari para waris bagaimana sebaiknya harta warisan itu dibagibagi.

Selama pembagian itu berjalan baik, rukun dan damai diantara para waris, maka tidak diperlukan adanya campur tangan dari orang luar keluarga bersangkutan. Campur tangan dan kesaksian tuatua adat atau para pemuka masyarakat hanya diperlukan apabila ternyata jalannya musyawarah untuk mencapai mufakat menjadi seret dan tidak lancar.

Hal ini dikarenakan saudara yang tertua laki-laki atau anak laki-laki dari saudaranya perempuan sangat dihormati oleh saudara-saudaranya. Dan juga sekaligus menggantikan kedudukan orang tuanya yang telah meninggal (apabila telah meninggal).walaupun saudaranya tertua yang memimpin musyawarah, tetapi tidaklah sewenag-wenang.

Adapun pembagian warisan pada masyarakat Desa Moolo Kecamatan Batukara Kabupaten Muna dilakukan pada waktu si pewaris masih hidup maupun si pewaris telah meninggal, dengan tetap menggunakan musyawarah mufakat. Pada waktu pewaris masih hidup, biasanya pewaris telah melakukan penerusan atau pengalihan harta kekayaannya pada anak tertua laki-laki. Apabila anak tertua perempuan, maka pewaris melakukan penerusan atau pengalihan harta kekayaanya tetap kepada anak laki-laki, walaupun anak laki-laki tersebut letaknya ditengah atau bahkan kecil sendiri dari saudara-saudaranya yang 
perempuan. Hal ini karena ada anggapan bahwa anak laki-laki lebih mumpuni atau cakap dibandingkan dengan anak perempuan. Sehingga apapun yang diputuskan oleh anak laki-laki, makasaudara-saudara

perempuannya tidak pernah lakilaki ini telah ditanamkan atau diajarkan oleh si pewaris kepada anak-anak perempuan mereka sejak masih kecil.

$\begin{array}{llr} & \text { Pada waktu } & \text { si pewaris } \\ \text { telah } & \text { meninggal, } & \text { pembagian } \\ \text { warisan } & \text { dilakukan } & \text { setelah }\end{array}$ semuanya telah tenang. Maksudnya tenang adalah semua ahli waris telah tidak lagi menangisi atau meratapi si pewaris yang telah meninggal.

Biasanya pembagian warisan dilakukan setelah seratus harinya si pewaris wafat. Karena selain tenang para ahli waris juga sudah berkumpul semua.

Setelah semua ahli waris berkumpul, maka secara otomatis anak tertua laki- laki atau anak laki-laki dari saudara-saudaranya yang perempuan langsung menjadi juru bagi.

Mengenai pembagian harta warisan setelah pewaris meninggal, adapula anak tertua pada masyarakat Desa Moolo Kecamatan Batukara Kabupaten Muna yang melakukan penguasaan warisan. Karena harta warisan itu merupakan milik bersama yang disediakan si pewaris untuk kepentingan bersama para anggota keluarga pewaris, sehingga anak tertua tersebut bertanggung jawab untuk menyelesaikan segala sangkut-paut hutang piutang pewaris ketika hidupnya dan pengurusan para waris yang ditinggalkan guna kelangsungan hidup para waris.

$$
\text { Pada masyarakat desa }
$$

Moolo Kecamatan Batukara Kabupaten Muna, hampir semua ahli waris adalah ahli waris yang berhak mewaris.

Hanya ada satu saja ahli waris yang bukan ahli waris, tetapi mendapat warisan. Hal ini dapat dilihat pada tabel 1(satu) berikut ini:

Tabel. 1

Perincian Pembagian Warisan

Bukan Ahli waris tetapi dapat warisan

\begin{tabular}{|c|c|c|c|c|}
\hline No. & NAMA & $\begin{array}{c}\text { NAMA AHLI } \\
\text { WARIS }\end{array}$ & $\begin{array}{c}\text { HARTA YANG } \\
\text { DITINGGALKAN }\end{array}$ & $\begin{array}{c}\text { CARA } \\
\text { PEMBAGIAN }\end{array}$ \\
\hline 1. & $\begin{array}{c}\text { Vetran } \\
\text { Taslim }\end{array}$ & La Ndiwasa & Sebidang tanah & sebidang tanah. \\
\hline
\end{tabular}

Sumber: Desa Moolo data primer, diolah, Tahun 20012 
Para pewaris yang ada pada masyarakat desa Moolo kecamatan Batukara Kabupaten Muna dalam membagi harta warisannya kepada waris adalah dari harta asal. Harta asal ini adalah harta kekayaan yang dikuasai dan dimliki pewaris sejak mula pertama, baik berupa harta peninggalan ataupun harta bawaan yang dibawa masuk kedalam perkawinan dan bertambah selama perkawinan sampai akhir hayatnya. Hal ini dapat dilihat dari harta warisan yang diberikan kepada waris berupa tanah persawahan yang masih terus ditanami oleh sipewaris sampai akhir hayatnya. Tanah persawahan tersebut berasal dari orang tuanya sipewaris, yang dikuasai dan dimiliki pewaris sejak mula pertama.

Perincian pembagian warisan pada masyarakat Desa Moolo Kecamatan Batukara Kabupaten Muna, sebagian ada yang bagian ahli waris perempuan lebih kecil daripada laki-laki. Namun ada juga yang bagian perempuan sama dengan laki-laki hal ini sangat tergantung musyawarah mufakat yang dilakukan para ahli waris. Mengenai perincian pembagiannya dapat diambil contoh sepuluh kepala keluarga dari responden yang ada. Ini dapat dilihat pada tabel 2 (dua) berikut ini.

Tabel. 2

Perincian Pembagian Warisan

\begin{tabular}{|c|c|c|c|c|}
\hline No. & NAMA & $\begin{array}{l}\text { NAMA AHLI } \\
\text { WARIS }\end{array}$ & $\begin{array}{l}\text { HARTA YANG } \\
\text { DITINGGALKAN }\end{array}$ & $\begin{array}{c}\text { CARA } \\
\text { PEMBAGIAN }\end{array}$ \\
\hline 1. & La Sandi & $\begin{array}{ll}\text { 1. } & \text { La domi } \\
\text { 2. } & \text { La Imi } \\
\text { 3. } & \text { La Sini } \\
\text { 4. } & \text { Wa Lisaana } \\
\text { 5. } & \text { Wa Miana } \\
\text { 6. } & \text { La Nifu } \\
\text { 7. } & \text { Jefri } \\
\text { 8. } & \text { Hasana } \\
\end{array}$ & $\begin{array}{l}\text { Sebidang Tanah } \\
\text { yang berisi pohon } \\
\text { kelapa dan coklat }\end{array}$ & Bergilir \\
\hline 2. & La Tulo & $\begin{array}{ll}\text { 1. } & \text { Wa Ndoahi } \\
\text { 2. } & \text { La gunti } \\
\text { 3. } & \text { La Sise } \\
\text { 4. } & \text { Latinggasa } \\
\text { 5. } & \text { Wa Ria } \\
\text { 6. } & \text { Undi Laduna } \\
\text { 7. } & \text { La Karimu } \\
\text { 8. } & \text { Lamilu }\end{array}$ & $\begin{array}{l}\text { Sebidang Tanah } \\
\text { yang berisi pohon } \\
\text { kepala dan coklat }\end{array}$ & Bergilir \\
\hline 3. & La Nuru & $\begin{array}{ll}\text { 1. } & \text { La Gande } \\
\text { 2. } & \text { La Ibu } \\
\text { 3. } & \text { La Baole }\end{array}$ & $\begin{array}{l}\text { 1. Rumah } \\
\text { 2.Tanah yang berisi } \\
\text { tanaman pohon }\end{array}$ & Bergilir \\
\hline
\end{tabular}


Pleno De Jure, Vol. 7 No. 2, Desember 2018

\begin{tabular}{|c|c|c|c|c|}
\hline & & $\begin{array}{ll}\text { 4. } & \text { La Tandu } \\
\text { 5. } & \text { Wa Odo }\end{array}$ & $\begin{array}{l}\text { kelapa dan } \\
\text { coklat. }\end{array}$ & \\
\hline 4. & $\begin{array}{l}\text { La } \\
\text { Polompu }\end{array}$ & $\begin{array}{ll}\text { 1. } & \text { La Sidi } \\
\text { 2. } & \text { Wa Hanifa } \\
\text { 3. } & \text { La Sise } \\
\text { 4. } & \text { Wa Ramo }\end{array}$ & $\begin{array}{l}\text { Satu kapling tanah } \\
\text { Kosong (40x40) } \\
\text { meter dan satu } \\
\text { kapling tanah yang } \\
\text { berisi tanaman } \\
\text { pohon kelapa ( } 40 \mathrm{x} \\
\text { 100) meter. }\end{array}$ & $\begin{array}{l}\text { 1. Wa Ramo } \\
\text { mendapat } \\
\text { bagian satu } \\
\text { kapling tanah } \\
\text { kosong seluas } \\
40 \times 40 \text { ) meter } \\
\text { dibagi } 3 \text { dibagi } \\
3 \text { (La Sidi, Wa } \\
\text { Hanifa, La Sise. }\end{array}$ \\
\hline 5. & La Ode Fadhe & $\begin{array}{l}\text { 1. Wd. Kamaria } \\
\text { 2.Wd. Sarpila } \\
\text { 3. Wd. Insaana } \\
\text { 4.Wd. Habiba } \\
\text { 5. Jufri }\end{array}$ & $\begin{array}{l}\text { Satu kapling tanah } \\
\text { kosong dan satu } \\
\text { kapling tanah } \\
\text { berisikan tanaman } \\
\text { pohon kelapa }\end{array}$ & $\begin{array}{l}\text { 1. Tanah } \\
\text { kosong dibagi } \\
\text { secara merata. } \\
\text { 2. Tanaman } \\
\text { yang berisi pohon } \\
\text { kelapa dipakai } \\
\text { secara bergilir. }\end{array}$ \\
\hline 6. & La Unsi & $\begin{array}{l}\text { 1..La angi } \\
\text { 2. Wa Sati }\end{array}$ & $\begin{array}{l}\text { Dua kapling tanah } \\
\text { yang berisi } \\
\text { tanaman kelapa. }\end{array}$ & $\begin{array}{l}\text { Masing-masing } \\
\text { mendapat } 1 \\
\text { kapling. }\end{array}$ \\
\hline 7. & La Ode Mbatu & $\begin{array}{ll}\text { 1. } & \text { Wd Sadidi } \\
\text { 2. } & \text { Ld. Suraili } \\
\text { 3. } & \text { Wd Tola } \\
\text { 4. } & \text { Ld Udin }\end{array}$ & $\begin{array}{l}\text { Enam kapling } \\
\text { tanah berisi } \\
\text { tanaman kepala }\end{array}$ & $\begin{array}{l}\text { Dibagi secara } \\
\text { merata. }\end{array}$ \\
\hline 8. & $\begin{array}{l}\text { Ld. } \\
\text { Hariminggu }\end{array}$ & $\begin{array}{l}\text { 1. Ld. Hamilu } \\
\text { 2. Waode Ati }\end{array}$ & $\begin{array}{l}\text { Tiga Kapling } \\
\text { Tanah berisi } \\
\text { tanaman kepala } \\
\text { dan coklat. }\end{array}$ & $\begin{array}{l}\text { Dibagi secara } \\
\text { merata. }\end{array}$ \\
\hline 9. & La Tinga & $\begin{array}{ll}\text { 1. } & \text { Biliati } \\
\text { 2. } & \text { Marsia } \\
\text { 3. } & \text { Rosmiati } \\
\text { 4. } & \text { La Joni } \\
\text { 5. } & \text { Harimini } \\
\end{array}$ & $\begin{array}{l}\text { Tiga Kapling } \\
\text { Tanah berisikan } \\
\text { tanaman kelapa }\end{array}$ & $\begin{array}{l}\text { Dibagi secara } \\
\text { merata. }\end{array}$ \\
\hline 10. & La Barani & $\begin{array}{l}\text { 1. Drs. } \\
\text { Mustafa }\end{array}$ & $\begin{array}{l}\text { Lima Kapling } \\
\text { Tanah }\end{array}$ & Dimiliki bersama \\
\hline
\end{tabular}


Pleno De Jure, Vol. 7 No. 2, Desember 2018

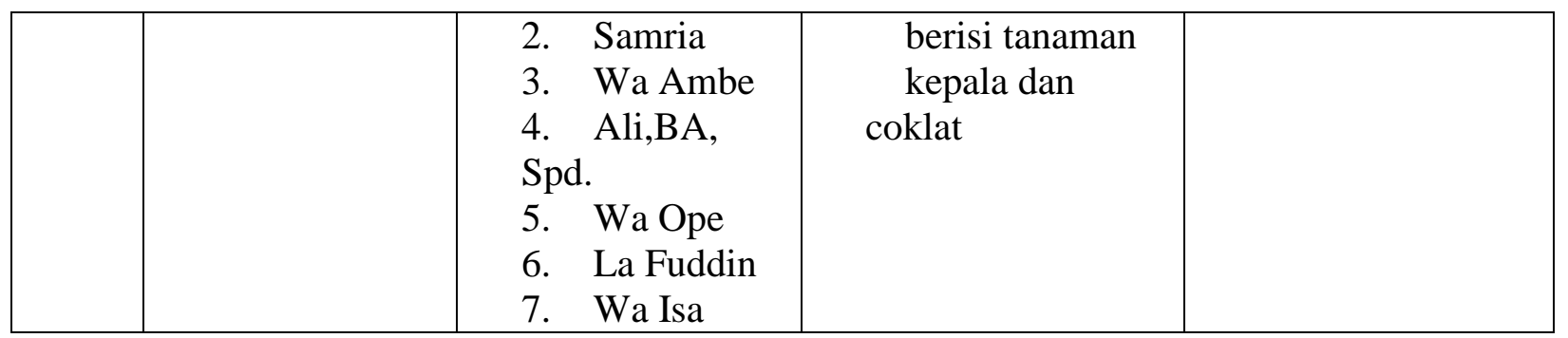

Sumber: Desa Moolo data primer, diolah, Tahun 2016

Pada masyarakat Desa Moolo Kecamatan Batukara Kabupaten Muna, banyak jug anak-anak dari si pewaris yang telah merantau ke kota dan berhasil. Dan ketika si pewaris meninggal mereka tidak meminta bagian warisan tetapi bagian warisan tersebut diberikan kepada saudaranya yang kurang mampu, sehingga saudarasaudaranya tersebut mendapatkan warisan yang lebih banyak dari bagian yang semestinya diterimanya.

Umumnya para ahli waris yang tidak mau mengambil warisannya, mempunyai alasan bahwa dengan diberikan bagiankepada saudaranya yang kurang mampu tersebut dapat meningkatkan kesejahteraan keluarga dari saudaranya yang tidak mampu tersebut.

Hal seperti ini diperbolehkan bagi ahli waris yang memang menginginkan seperti itu. Tapi sekali lagi juru bagi mempunyai peranan yang penting yaitu menanyakan kepada ahli waris yang ingin memberikan bagian warisan tersebut kepada saudara-saudaranya yang kurang mampu(ahli waris lainnya), mengenai tidak adakah masalah atau meminta kembali bagiannya setelah bagiannya diserahkan,oleh keturunan ahli waris yangmemberikan bagian warisannya tersebut. Sangatlah penting untuk ditanyakan, karena bisa menjadi suatu masalah yang besar apabila suatu hari nanti keturunan ahli waris tersebut meminta bagian dari pada orang tuanya yang telah memberikan bagian warisannya tersebut, kepada saudara-saudara orang tuanya yang kurang mampu tersebut.

Masyaraka Desa Moolo

Kecamatan Batukaran Kabupaten Muna membagi warisan secara Hukum Waris Adat semacam ini, dengan alasan bahwa mereka mengikuti jejak-jejak yang telah diajarkan orang tuanya lebih dahulu atau nenek moyang atau leluhur. Sehingga pembagian warisan denga cara musyawarah mufakat (Hukum Waris Adat) seperti ini sudah biasa dilakukan.Maka apabila mereka melihat orang kota yang membagi warisan dengan dibagi-bagi menurut aturan (hukum waris Islam, lebih-lebih Hukum Waris Barat/BW) malah heran. Karena dalam pikiran mereka, membagi dengan cara ditentukan menurut aturan (hukum waris islam, lebih-lebih hukum Waris Barat/BW) dapat merenggangkan hubungan persaudaraan atau kekeluargaan antara para ahli waris. Bagi mereka menjaga hubungan kekeluargaan atau 
persaudaraan lebih penting daripada memperebutkan harta warisan Harta tidak akan dibawa kalau mereka meninggal, begitulah falsafah yang ada pada masyarakat Desa Moolo Kecamatan Batukara Kabupaten Muna.

Wawancara dengan masyarakat desa Moolo Kecamatan Batukara Kabupaten Muna.

\section{BAB IV PENUTUP}

\section{A. Kesimpulan}

1. Alasan-alasan masyarakat desa Moolo Kecamatan Batukara Kabupaten Muna menggunakan cara musyawarah mufakat adalah, karena membagi dengan cara seperti ini mengikuti jejak- jejak orang tuanya lebih dahulu atau nenek moyang atau leluhur yang telah mengajarkan kepada mereka. Selain itu, mereka juga berpedoman bahwa harta peninggalan orang tua itu tabu untuk diperebutkan.

Selain kedua alasan itu, ada alasan yang sangat fundamental bagi mereka yaitu mereka berpedoman Tuhan maha kaya. Selain itu masih ada alasan lain mengapa masyarakat Desa Moolo Kecamatan Batukara Kabupaten Muna membagi harta peninggalan si pewaris secara Hukum Waris Adat, yaitu harta peninggalan orang tua harus dilestarikan sebaikbaiknya dalam artian bahwa harta peninggalan dari si pewaris itu harus dijaga sebaik-baiknya, tidak boleh dipergunakan atau bahkan dijual dengan hasilnya dipergunakan untuk keperluan yang tidak penting.

2. Implementasi penyelesaian segketa warisan yang terjadi pada umumnya di masyarakat Desa Moolo Kecamatan Batukara Kabupaten Muna, adalah selalu menggunakan musyawarah mufakat untuk menyelesaikannya. Semua responden beragama islam dan pernah melakukan waris-mewaris, baik sebagai ahli waris maupun sebagai pewaris. Walaupun mereka beragama islam dan menjalankan ajaran agama islam dengan sungguh-sungguh, tapi kalau urusan waris-mewaris mereka menyelesaikannya tetap menggunakan Hukum Waris Adat. Hal ini menunjukan bahwa Hukum Waris Adat masih sangat kuat ada pada masyarakat desa Moolo Kecamatan Batukara Kabupaten Muna, engalahkan hukum waris islam dan lebih-lebih Hukum Waris Barat (BW).

Kuatnya penggunaan Hukum Waris Adat dalam hal warismewaris, mengalahkan hukum waris slam lebih-lebih Hukum Waris Barat (BW) adalah karena dalam pikiran masyarakat desa Moolo Kecamatan Batukara Kabupaten Muna menyelesaikan waris-mewaris dengan bagaimana baiknya lebih bagus dibandingkan dengan menyelesaikan warismewaris dengan diatur oleh adanya suatu ketentuan.

Pembagian warisan dengan diatur oleh suatu ketentuan hanya akan menimbulkan rasa ketidakikhlasan di hati mereka (ahli waris).Masyarakat Desa Moolo Kecamatan Batukara Kabupaten Muna mempunyai prinsip bahwa segala sesuatu itu harus dilandasi dengan rasa ikhlas

\section{B. Saran}


1. Diharapkan penyelesaian sengketa warisan diluar pengadilan ini dapat berjalan terus sampai anak cucu mereka dan seterusnya pada masyarakat desa oolo Kecamatan Batukara Kabupaten Muna. Sehingga rasa persaudaraan dan kekeluargaan diantara mereka (para ahli waris) dapat terjaga dan terpelihara. Kalau rasa persaudaraan dan kekeluargaan telah terjaga dan terpelihara, maka permusuhan tidak akan pernah ada.

Hati akan menjadi tenang dan tentram, dan juga sipewaris yang telah meninggal di alam kubur sana bisa beristirahat dengan tenang.

2. Juru bagi seharusnya bertanya kepada seluruh ahli waris, mengenai bagian yang telah diterima. Apakah bagiannya tersebut telah sesuai dengan bagian yang seharusnya diterimanya (menurut keinginannya). arena pada umunya ahliwaris tidak pernah mengutarakan, apa yang diinginkannya tersebut. Mereka selalu menerima dengan ikhlas berapapun jumlah bagiannya tersebut. Pada hal sebenarnya bagian warisannya tersebut dipergunakan untuk mencukupi kebutuhan sehari-hari. Sehingga akhirnya mereka untuk mencukupi kebutuhan sehari-hari dengan meminjam uang dari tetangga kanan kirinya (padahal mereka sebenarnya tidak perlu meminjam uang, kalau mau mengutarakan keinginannya tersebut).

\section{DAFTAR PUSTAKA}

Bushar Muhamad, 2001, Pokok-Pokok Hukum Adat, Pradiya Paramita. Jakarta

Bzn, Ter Har, 2000 Asas-asas dan Susunan Hukum Adat,Alumi, Bandung

Goysal, A. H. (2015). Kontradiktif Penerapan Azas Retroactive Dalam Mengadili Hak Azasi Manusia di Pengadinal HAM Adhoc. Pleno Jure, 4(5), 13-27.

Hilman Hadikusuma,2003, Hukum Waris Adat, Penerbit Alumni, Bandung,

Iman Sudiyat, 2001, Asas-Asas Hukum Adat Bekal Pengantar,Libert Yogyakarta,

J. Lexy Moleong, 2006, Metode Penelitian Kualitatif, Remaja Rosda Bandung.

Rahmad Budiono,1999, Pembaruan Hukum Kewarisan Islam Di Indonesia, Penerbit PT Citra Aditya Bakti, Bandung,

Rachmad Syafa'at, 2006 Advokasi

Dan Pilihan Penyelesaian

Sengketa (Latar Belakang, Konsep, dan Implementasinya), Agritek YPN, Malang.

Ronny Hanintijo Soemitro,2002 Metodologi Penelitian Hukum dan Juri Metri, Ghalia Indonesia, Semarang.

Soepomo ,2000, Hukum Perdata Adat, Njambatan, Jakarta. 
Pleno De Jure, Vol. 7 No. 2, Desember 2018

Soepomo, 2000, Bab-Bab Hukum Waris, Pradiya Paramita, Jakarta.

Seorojo Wirjodipoero,2002, Pengantar dan Asas-asas Hukum Adat, Haji mas Agung, Jakarta,

Subekti， R, Dan Tjitrosudibio, R, 1999, KitabUndang-undang Hukum Perdata, Pradnya Paramita, Jakarta.
Saragih,2000,Pengantar Hukum Adat Indonesia,Trasito,Bandung.

Suparma Erman,2005,Hukum Waris Indonesia.Rafika

Aditama,Bandung.

Suyud,Margono,ADR,2000.

Alternative Disputes Resolution dan Abritase: Proses Pelembagaan dan Aspek Hukum, Ghalia Indonesia.Jakarta. 